\title{
Mentoring Tradeoffs: Breaking into the World of Academe
}

\author{
Kathleen Y. Terry \\ The TEEG Ventures Group, \\ Alpharetta, GA, USA
}

kphd@bellsouth.net

\author{
Robert DeMichiell \\ Robert DeMichiell and \\ Associates \\ Pompano Beach, FL, USA
}

demich@earthlink.net

\section{Clarence Williams \\ Williams Consulting Group, Inc. Duluth, GA USA}

\author{
info@wcginc.net
}

\begin{abstract}
"A wise person once said that the re is nothing new under the sun, that whatever the challenge may be, it has been overcome before. A good mentor can show you ne w ways of tackling even the most common problems." (Bourne, 2002).
\end{abstract}

\begin{abstract}
Much has been written in recent years on the subject of mentoring and many universities, organizations, and individuals have rushed to embrace the concept without thinking through what it means for the university, organization, mentor, and, most importantly, the mentee. This article is an examination of the various factors involved in the mentoring process. Knowledge gained, collaboration, situational learning, and social networking are discussed as key components of the mentoring process. As information was collected for this article, some of these comments were derived from extensive experience over several decades and more recently, comments from a recent professional business person who has just acquired a doctorate. For the seasoned academic professor, it was a time to reflect on the major issues of mentoring and to organize the discussion for this most important aspect of education, particularly focused on higher education. In the latter case, the purpose of gaining the terminal degree was to enter into academe, start a new career, and bring a wealth of business acumen and experience to the classroom for the ultimate benefit of students.
\end{abstract}

Material published as part of this publication, either on-line or in print, is copyrighted by the Informing Science Institute.

Permission to make digital or paper copy of part or all of these works for personal or classroom use is granted without fee provided that the copies are not made or distributed for profit or commercial advantage AND that copies 1) bear this notice in full and 2) give the full citation on the first page. It is permissible to abstract these works so long as credit is given. To copy in all other cases or to republish or to post on a server or to redistribute to lists requires specific permission and payment of a fee. Contact Publisher@InformingScience.org to request redistribution permission.
Keywords: Mentoring, Mentor, Mentee, Neophyte, Practitioner

\section{Introduction}

Mentoring sets out to get the balance right by helping existing and potential mentors to examine what they do, and how and why they do it (Brown, 2008). Encouraging the mentor to think, reflect on past experiences and draw conclu- 
sions helps the mentor develop better leadership and mentorship skills. By drawing from two perspectives: the mentor and mentee, the authors discuss the issues, problems, and solutions addressed not only by the players (faculty, prospective faculty), but also by academic administrators who set the rules for the hiring process, and therefore examine the formal or informal interaction among these players. Without full support and encouragement, one has only to rely on the intrinsic value to the mentor for helping new faculty. Figure 1: Mentoring Tradoffs Illustrated demonstrates some of the situations that students encounter when completing their education and want to move into the academic setting. Many of these students have been working in organizations of many years, which experience they bring to the university. Figure 2: Issues presented by Mentor / Mentee depict some of the summarized issues that are encountered frequently. The diagrams depict the dilemma and set the stage for a more organized discussion of the five issues in Figure 2 .

\section{Theoretical Framework for Mentoring}

\section{Situational Learning}

In conducting research on mentoring, the concepts take on many different names. The work performed by an experienced individual has been sometimes referred to situational learning through the neophyte and the practitioner, social networking between an executive and the new manager of an organization, and a professor to a new graduate entering into the world of academe. Work on situational learning (Chaiklin \& Lave, 1993; Hanks, 1991; Lave, 1991, 1996; Lave \& Wenger, 1991; Rogoff, 1990, 1991, 1995; Wenger, 1998) has helped them follow the gradual transformation of neophyte into practitioner (Le Maistre, Boudreau, \& Pare, 2006). This movement occurs through what Rogoff calls "guided participation," and what Lave and Wenger call "legitimate peripheral participation" (Le Maistre et al.). The descriptions by these researchers are centripetal: the leaner is drawn from initial, hesitant performance toward proficiency.

Under the guidance of more experienced individuals, newcomers can engage in practice which is legitimate (that is, worth to the functioning of the organization, rather than contrived), peripheral (failure to accomplish the task does not damage the organization, but be redone by the newcomer or can be remedied by experienced practitioners), and participatory (the newcomer is engaged in tasks of increasingly complexity, rather than being an observer). By engaging newcomers in authentic but not critical or central tasks, by gradually increasing both the difficulty of the work and the autonomy of the learner, and by the subtle application of just-in-time teaching and assessment, old timers create a centripetal force that pulls these newcomers toward capable, central partic ipation in the community's activity. (Le Maistre et al., 2006). The learning that occurs from a mentorship relationship between the mentor and mentee can be used for the rest of their lives.

\section{Social Networking and Collaboration}

Social networking and collaboration are two key components in the mentorship process. Social networking ties together the interdependencies of the mentor's values, and visions with the mentee. Collaboration is a process by which the mentor works together with the mentee to achieve a common goal. They both can work together to share knowledge, learn and build consensus between each other.

\section{Knowledge / Knowledge Transfer}

Mentoring requires a particular set of skills and know ledge. Mentees need to be guided by more know ledgeable practitioner who can contribute to the mentees' development as a future teacher. 
When formal training or knowledge transfer is the objective, the interaction tends to be primarily between instructor and student (or expert and novice) and structured around a discrete problem, assignment, or lesson plan (Zack, 1999). This is referred to as distributed learning (Zack, 1999). Knowledge transfer in an organization is the process through which one unit, group, department, or division is affected by the experience of another (Argote, 1999). Experience has shown that transferring know ledge, whether at the individual, group, product line, department, or division level is usually a laborious, time-consuming, and difficult task (Kwan \& Cheung, 2006). People drink in knowledge informally and unconsciously. They learn much incidentally, while eating in the cafeteria, chatting in the halls, observing the ir colleagues' and supervisors' behavior, and through the vicarious experience of others (Swap, Leonard, Shields, \& Abrams, 2001). For mentoring, it can be time consuming. It takes a dedicated person who is organized in their daily planning to be a mentor. For the mentee, it takes dedication and commitment to the relationship and the goal should be to learn from the experience of mentorship.

Gray (1999) identified five ways knowledge can be generated: acquisition, dedicated resources, fusion, adaptation, and networking. Acquisition occurs through both internal and external sources. It can be bought from consultants and universities, or by acquiring a company. Dedicated resources usually come in the form of research and development or training departments. Fusion brings people together with different perspectives in multidisciplinary teams. The individuals in the teams share their knowledge to arrive at solutions. Adaptation involves creating solutions to meet changing conditions. Networking is sharing, then creating new knowledge by informal selforganizing networks. Effective know ledge transfer requires trust; it also requires that people absorb the knowledge. Trust is a key factor in a successful relationship between the mentor and mentee.

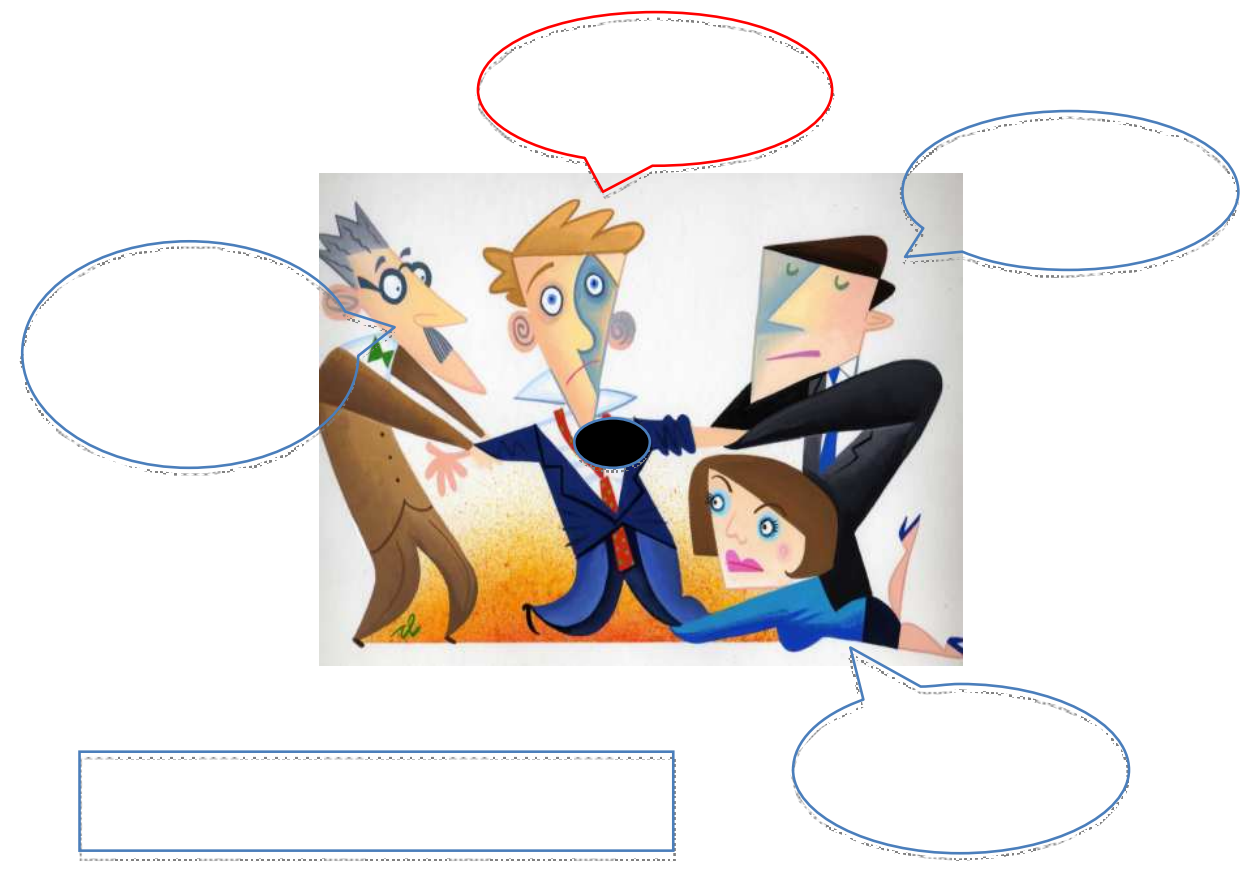

Figure 1: Mentoring Trade-offs Illustrated 
Mentor Perspectives

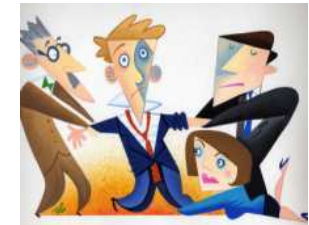

\section{Person Mentored:}

Some Issues for a Professi onal Academician

1. Required for promotion or advance ment?

If yes, how many persons

should I mentor?

If no, other extrinsic/intrinsic benefits?

2. Compati bility with myscholarly work.

3. Personality compatibility.

4. Presentation/publication opportunities.

5. Time/schedul e available for interaction.
Some Issues for Aspi ring Academician

1. Required for progam completion?

If yes, who do I approach?

If no, other extrinsic/intrinsic benefits?

2. Compati bility with myscholarly work?

3. Personalitycompatibility?

4. Does mentor havesolid record of teachingas well as publication experience?

5.Does mentor have timeto interact and meet my schedules?

Figure 2: Issues presented by Mentor / Mentee

\section{Issues presented by Mentor / Mentee}

Mentoring is recognized as a key developmental resource for individuals in organizations and universities (Noe, Greenberger, \& Wang, 2002). Mentoring has been described as "the most intense and powerful one-on-one developmental relationship, entailing the most influence, identification, and emotional involvement" (Wanberg, Welsh, \& Hezlett, 2003) between a more experienced professional and a less experienced individual. The majority of research has explored mentoring from the vantage point of mentee perceptions, reactions, experiences, and development (Kram, 1988).

A report by David Cutterbuck, following mentoring programs in leadership positions, found that as a result of being mentored:

- $90 \%$ of mentees were more conscious of their own values;

- $84 \%$ felt more secure in their leadership roles;

- $82 \%$ believed that the program had a positive effect on their career development;

- $80 \%$ reported that they had developed personally (Cutler, 2005).

Mentoring study participants have commonly been employees, college students, and midlevel managers. The following issues (1 through 5) be low express responses from the mentor standpoint (faculty member, seasoned professor, and consultant) and from the mentee standpoint (seasoned consultant, corporate executive, and new professor-faculty member).

\section{Issue \#1: Mentoring "Requirements"}

\section{Perspective of Mentor}

The higher education institution may or may not have listed requirements for mentoring. Furthermore, what is meant by mentoring? It may simply be just to list availability of the faculty 
member (days/hours per week) on the door for any type of counseling. Generally, these arrangements are focused on undergraduate students who may need help with coursework and/or other personal matters. In this article, we are directed to graduate students, who may or may not be available to meet any prearranged hours because of work requirements, or to colleagues, who may be part-time or full-time faculty and who may or may not have the doctorate. If that person does not have the doctorate, or is in the process of achieving it, these comments may be especially helpful.

What would be the incentive for faculty to be involved in a formal or informal mentor program? If that person is truly a professional academician, the intrinsic value would be important: helping their colleagues adjust to the life, think about conference presentation or journal publication, converse intellectually about the subject matter, serve the institution or the community.

Sometimes, as Figure 2 suggests, mentoring can be overwhelming. Mentoring does take time away from one's own professional development. If tenure looms on the horizon, there is a requirement for publication that is difficult to avoid, even if the institution markets itself as primarily a teaching institution. If this is the case, then the publication could be expected in teaching methodology rather than strict research. There are many venues for reports on teaching effectiveness such as the use of case studies, experiential exercises, computer simulation, team-teaching of standard and multidisciplinary courses, and other project-oriented courses perhaps even conducted at sites other than the classroom.

On the plus side for the mentor, it may be an opportunity to collaborate on publishing with a partner who can share the workload. The partner may very well bring a fresh perspective to the subject, or collect data, or even write the first draft of the paper. It is the experience of the authors that this subject of collaboration can be abused by a conscious effort merely to increase the number of publications. Here, we suggest that some agreement is met at the outset about who will do what work and when it will be done. There must be an equitable share of effort by all authors with the lead author taking charge and ensuring that the publication deadline is met, the paper is written correctly, and the required format is followed.

These requirements probably would not be stipulated by the institution, but must be addressed by the interested parties.

\section{Perspective of Person Mentored}

Mentoring is an emancipatory act. Although the term "mentor" has been appropriated in some professions to include notions of assessment, the pure conception of mentoring is to encourage personal growth. Within this framework a trusted mentor can be a key person to help reflection. The mentor can help by encouraging questioning of the governing variable(s), support the mentee in their journey from the known into uncharted territory, and focus on learning opportunities. (Lee, 2007)

From the perspective of the person mentored either as a graduate or doctorate student, the relationship can be ongoing, irregular, or of very short duration, however, these interactions have a profound impact on the future direction of the young individual. Many times these interactions provide a roadmap for the success or failure of the young individual (Ugrin, Odom, \& Pearson, 2008). The mentee must hold up their end of the relationship too. They can be expected to

\section{Commit to learn}

Have genuine interest

Use active listening skills

Be receptive to feedback

Be willing to take risks desire career growth

Desire to develop a personal vision ("Ten points to help you sell...," 2007). 
When a student is confronted with a graduate or doctorate schedule for completion of their degree, a collection of information needs to be obtained by them. First they should communicate (encourage dialogue) to the entire faculty that pertain to their major and their administration. Second, they need to seek out a mentor or someone whom they can look upon to assist with their schedule of classes, to work with them as a person whom has already been through the demanding ordeal of graduate or doctorate school. Finding a person they can trust, encourage, and stimulate the student/mentee's thinking is very important. Some of the best mentors for the student/mentee offer advice they do not want to hear. They chide us, goad us, challenge us in ways we would not have done on our own (Rose, 2008).

Intrinsically, the student/mentee should be aware of the positive aspects of having a mentor during their graduate or doctorate program. The student/mentee should research ways to ensure that they are performing to the best of their abilities in school. Identifying resources to utilize would be very important to know before they approach a possible mentor. Extrinsically, the student/mentee should seek out a mentor who can offer guidance, not be judgmental, have patience, challenge ideas, and offer advice, not only from an academic standpoint, but also from a practitioner standpoint. Having a mentor can be someone whom you are able to draw on their knowledge. Using this knowledge can influence your thinking and behavior even when they are not available. A true mentor is one who looks at the relationship as two-way traffic. They should derive as much pleasure from being your mentor as you do in benefiting from the ir expertise. It is important to seek out stimulating questions we ask the mentor as it enables the mentor to think things through anew for themselves (Catling, 2008). Seeking a mentor should be a welcome experience and should make you feel great about yourself. If someone of that caliber endorses your work and tells you that you are a good conscientious student/mentee, then it really is a boost (Catling).

There are 10 key qualities that help a student/mentee relationship with a mentor:

- Humility-be able to accept and utilize constructive criticism.

- An open mind-have no preconceived ideas of how the relationship will go.

- Willingness to listen - learn to quiet your mind so that you can fully absorb what is being said. The moments with mentors are fleeting and precious.

- Curiosity — ask why, how, when, and where; be full of questions.

- Lateral thinking - when you hear advice, think of all the ways that it could be applied.

- Patience - it takes time to build a quality relationship of any sort.

- Tenacity-make the effort to stay in touch, be proactive.

- Integrity - it is critical that both mentee and mentor demonstrate integrity, civility, and respect right from the start of the relationship. Always give the mentor feedback on how their direction or advice is working out for you.

- Honesty-be willing to tell the whole truth to your mentor. They cannot give you proper help if you do not.

- Time - time spent with your mentor is an investment; look after it wisely. Keep in touch with your mentor in good times as well as when the going gets touch (Catling, 2008).

\section{Issue \#2: Compatibility with Scholarly Work}

\section{Perspective of mentor}

One has to evaluate carefully the nature of the higher education institution for selection of a collaborator for scholarly work. For some disciplines, the field of vision for the subject may be narrower than others, and the qualifications and experience of a publishing partner also may be narrow. In these situations, the compatibility issue is easier to resolve. Collaboration is organized 
and focused, tasks are easy to identify and allocate depending on interest and experience of the individual researchers, and it has been established that the Department Head, or Dean of the School, has encouraged and will accept the work. It will contribute favorably to the pay, promotion, and tenure process.

One caveat, however, is that the committee for this process may have different ideas about the meaning of scholarly work. Different institutions have different criteria and processes for the path to academic success and it behooves the pursuer to determine the rules, regulations, and spirit of those regulations before any long and tedious research effort is undertaken. This approach is true also for undertaking any new and nontraditional teaching methods.

Does the institution agree with such new methods? You may be collecting data for a new teaching method (e.g. bringing students directly into a business working environment to interview real workers and make recommendations for improving productivity) and discover later that the educational norm is traditional classroom lecturing. In fact, other faculty may be jealous of your students' very positive reaction to bringing reality to theory through this practicum. Also, this same faculty may serve on the pay, promotion, and tenure committee.

For those disciplines where the collaborative path is not so clear, and therefore the compatibility issue becomes more of a problem, one approach is to look for that diversity of opinion and capitalize on that incompatibility. If the research effort is on marketing strategies, the idea of introducing more global and multicultural aspects can make the outcomes more appealing to this wider audience. If the research activity centers on teaching methodology, role-playing and research by students studying production and sale in a foreign country might provide a more interesting topic for discussion.

Team-teaching activity highlights another compatibility issue. Why team-teach in the first place? Administrators may not encourage it because it means more overall faculty is needed to teach the same courses, which means more expense. Mentors can provide valuable insight for new faculty in teaching techniques, developing rapport with students, encouraging different points of view for the subject matter, and perhaps different grading practices, both individual and team, for student performance.

\section{Perspectives from person mentored}

Often students and / or mentees presume that they need someone who is an expert in a given field, which is important, but having someone who takes a personal interest and professional interest in your career and personal development would be what mentoring is really about (Durett, 2006). Figure 3 shows that $27 \%$ of the participants who answer the below questionnaire stated that the mentor provides ins ight into a particular field or industry. From the below results, this was second to the highest of importance to the mentee filling out the questionnaire.

\section{Issue \# 3: Personality Compatibility}

\section{Perspectives of mentor}

Right brain, left brain, and "combination" thinking skills between mentor and prospective faculty member can provide the diversity needed to be both creative and productive in any collaborative research and/or publication effort. If there is a close match between the two persons, it could be a very efficient process and meet the deadlines right on schedule. This effort is good for each contributor because not much time is wasted before and during the meetings and the individual project work directly pertains to the agreed upon topic. On the other hand, diversity of opinion on the topic, including the nature, scope, and work allocation can be very inefficient, but in the long run the result may be more effective. Contemplation and reflection may very well pay off when the 


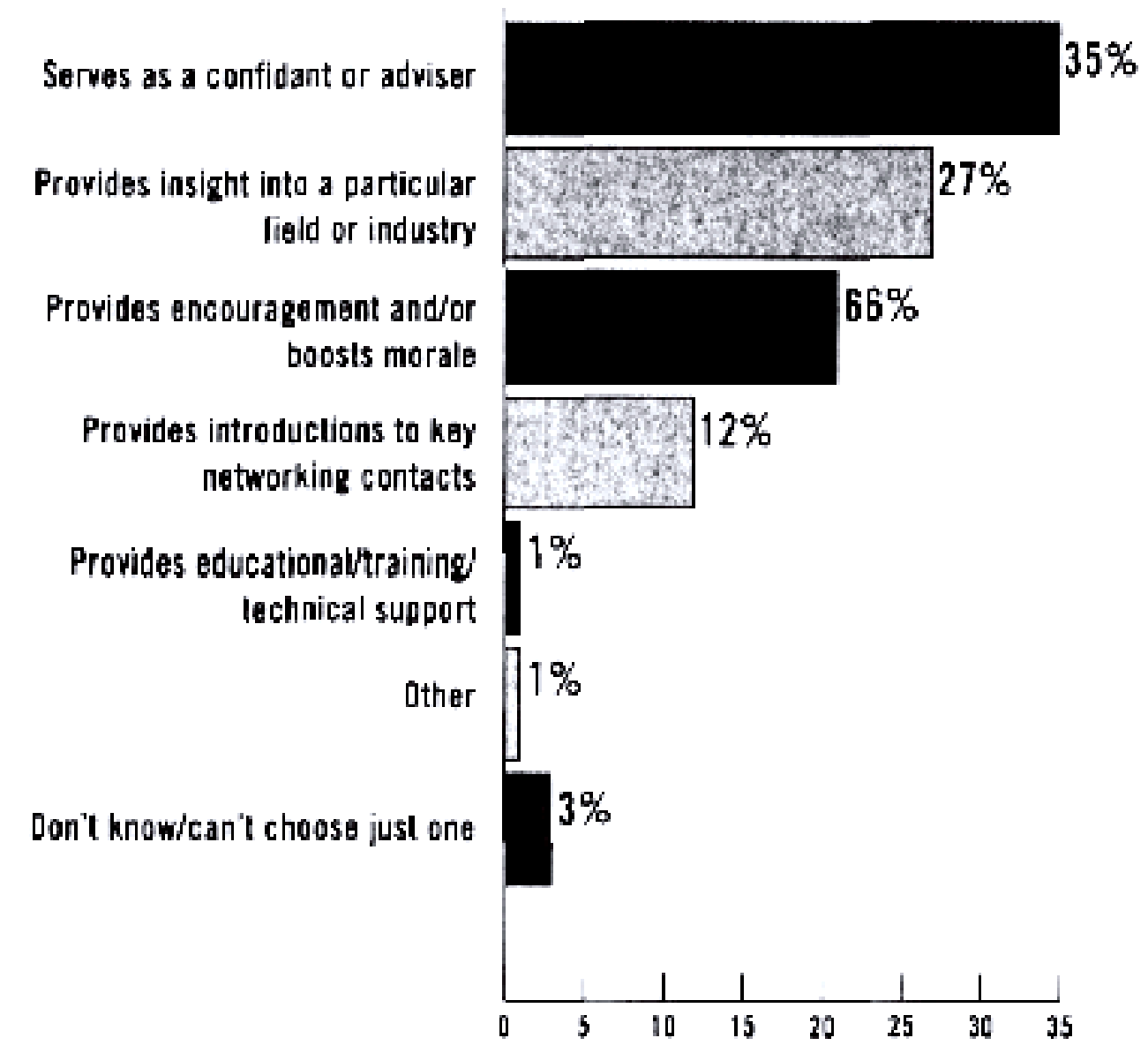

\section{Source: Accountemps}

Figure 3: Mentee Survey Results from Questionnaire From Durett (2006)

proper approach is carefully chosen and the process allows examination of some tangential issues, some of which may not have been contemplated at the outset. The process takes longer and may be perceived by each worker to be the wasteful pursuit of irre levant variables.

However, it should be clear at the outset that such similar or different thinking styles are known and act accordingly. Personality factors do enter in the equation of collaboration and unconsciously, either or both of the workers should consider this aspect before commitment of any major effort. The authors have witnessed many false starts on writing texts, chapters in texts, and other major writing projects because of the failure to consider personality traits and thinking skills as important in the collaborative process.

With false starts, the major problem is that much time is wasted with no output. The effort may be included in the resume as "work in progress" but sooner or later the net result has to be reported. Reviewers of articles, tenure committee members, and other readers of the resume, are not interested in the incompatibility of coworkers, or any other excuse, regarding the effort. Results are rewarded; project work is only commendable. 
Terry, DeMichiell, \& Williams

\section{Perspectives of person mentored}

Postgraduate supervision, until recently, was regarded as an extension of research rather than as a form of teaching. Research students were assumed to be "always/already" autonomous scholars at the beginning of the ir candidature. So too, postgraduate mentors were assumed to be always/already effective at supervising once they had endured the process themselves (Manathunga $\&$ Goozee, 2007). For students entering into the teaching profession, postgraduate supervision is regarded as a form of mentoring, where students gradually master appropriate disciplinary research knowledge. Yet, mentors also wrestle with the contradictory role of disciplinary gatekeeper. As a result, the always/already autonomous student and effective mentor/mentee relationship remain strong in supervision pedagogy (Manathunga \& Goozee, 2007). The relationship may continue on after the student graduates and become a full professor at the university.

Both individuals and organizations use mentoring relationships to enhance learning and professional and personal deve lopment in the workplace (Wanberg et al., 2003). There are two types of mentoring: formal programs and informal relationships.

Formal mentoring occurs in a structured environment where a third party pairs the mentor and mentee together. Most formal relationships are structured with certain requirements and time frames (Rosser \& Egan, 2003). Informal mentoring develops spontaneously and voluntarily. Most informal relationships are unstructured, flexible, and usually intimate because the mentor and mentee mutually identify and volunteer to be in the relationship. (Rosser, 2005)

Three factors contribute to the success in working with a mentor: mentoring style, the process of integrating multiple resources and models, and the gradual alignment of the student/mentees' expressed verbal know ledge and teaching practices (Schmidt, 2006).

- Mentoring Style: if the student/mentee is pursuing teaching after graduation, then the mentor may need to observe their teaching style. The mentor should demonstrate through example, the style of their own teaching and have the student/mentee observe on a regular basis. Giving constructive feedback when the student/mentee is teaching is also a good way to show support. Guiding the student/mentor through actual demonstration is a good style for the mentor.

- Multiple Resources and Models: using a principle-oriented style (Franke \& Dahlgren, 1996). This style seems to help clarif "confusion" or explain the reasons behind suggestions, an aspect that is often miss ing from the mentor's recommendations. If the student/mentee clarified their own philosophical be liefs about their knowledge and felt "comfortable" to them, then they seem to develop the self-confidence to make their own decisions about whether to seek advice from the mentor (Schmidt, 2006).

- Expressed Verbal Knowle dge and Teaching Practices: as the student/mentee demonstrates a positive outcome of the ir finished tasks, the mentor should discuss the results verbally with the student/mentee. The mentor should allow the student/mentee to express themselves via presentation of results in front of a small group of faculty and / or professionals. The student/mentee should also demonstrate through teaching methods, specific teaching practices that are taught to them by the mentor.

\section{Issue \# 4: Presentation/Publication Opportunities}

\section{Perspectives of mentor}

There are some individuals who see presentation/publication opportunity around every corner. Others may wait for the telephone or email to provide them specifically with an opportunity to participate. There may be some faculty who are not interested in opportunity at all; these persons 
are swamped with teaching loads, service to the institution or community, consulting activity, and many personal life commitments or problems.

Comments here are based on the first category and fit the perspective of the authors. With this perspective, there is one problem and it concerns the notion that all opportunities should be pursued. Certainly, one has to be selective in this mode otherwise the plate will be too full, everyone will be after you because you cannot say no, and then you will be overextended with commitment.

There are some universities that have no upper limits on the number of persons you can mentor. In the case of doctoral student programs, some faculty may serve in the mentoring capacity on several doctoral committees. Several may mean a handful, or it may mean a dozen, or perhaps even 20 or more. The question is: How many students can one mentor effectively? Payment according to the number of students is one motivation to maximize this effort. Publication by the mentor is another motivating factor because the topic and its development into publishable material may very well be the brainchild of the mentor in an ongoing research activity.

In those cases where the situation is between faculty colleagues and not faculty-student related, the mentor should pursue opportunities to advance scholarly work in his/her discipline and perhaps also engage in multidisc iplinary activity. This work enhances one's credibility and the academic stature of the institution. Presence at regional, national, and international conferences allows one to meet colleagues from other institutions and countries, and therefore provides many ideas and opportunities for further exploration.

Professional activity in one or more of these conferences, journals, or institutes builds personal and institutional credibility, and again, may provide the inside track to participate in scholarly work not imagined previously. Some of these venues provide for student work as well and may precipitate publication ideas in this direction. Much of this scholarly activity has a "trickle down" effect and may lead to student and faculty exchange program development, project work in business or government environments, and other unintended activity not foreseen at the outset. Once the mentor has achieved some recognition and reward, opportunities increase. Then, it becomes a problem of even more selection of opportunity to follow and who to lead onto what path of opportunity as a mentor. The mentor must navigate through a sea of opportunity with the right crew and with certain selective courses and destinations.

\section{Perspectives of person mentored}

The ideal mentor should have the appropriate background of knowledge and a solid record of teaching as well as publication experience. The knowledge-base should be in the sector-specific area similar to that of the mentee. Having a record of developing and motivating others should be a key factor in choosing a mentor. The mentor should not be directly related to the mentee's current or chain of command (Cutler, 2005). That way, the mentee will feel more comfortable and confident working with the mentor.

\section{Issue \# 5: Time and Schedule for Interaction}

\section{Perspectives of mentor}

For faculty and undergraduate students, the situation is easily solved because most institutions of higher learning post minimum hours for consultation, by appointment or just walk-in. For graduate students, in either master's programs or doctoral programs, there is more of a problem. If hours are posted, students who work cannot be there during the day. Hours usually are not posted in the evening. Therefore, the only recourse is to see the teacher before or after class, if in fact 
that teacher is the one sought for mentoring. You may not be taking any classes that semester, or cluster or you may be engaged in online learning, in which case you may never see the teacher.

From the perspective of the mentor, you would only see those students who can step over these hurdles and gain some time with you. In other words, the system is in your favor, unless you are sincerely interested in the mentoring process. In this case, you have to make yourself accessible to students through other means, such as clubs, sports, institutional programs, and other extracurricular activities.

Once the connection is made and other issues of the collaborative effort have been examined, as noted in the rest of this article, then some guide lines about time and schedule for interaction can be entertained.

\section{Perspective of person mentored}

There are two factors before agreeing to a mentoring relationship: time commitment and personal fit (Pieper, 2004). There has to be a commitment to this relationship on both sides. The stu$\mathrm{dent} / \mathrm{mentee}$ has to be prepared for meetings, respond to emails and telephone calls, and work with the mentor on his or her coursework for your degree (Pieper).

A good mentor candidate would:

- Be committed to personal and organizational development;

- Exhibit a calm, steady demeanor;

- Possess training, coaching, and counseling skills;

- Have a positive work history and be in good standing w ith the university/organization;

- Continue to associate and be familiar with department members; and

- Demonstrate communication ability (Schrage, 2007).

There are common mentoring mistakes to be aware of:

- Picking the wrong mentor - both student/mentee and mentor should feel free to refuse a mentorship if their values do not match the other person's values, or if they question the other person's motives for wanting the mentorship.

- Lecturing rather than listening — one of the hardest things to avoid, the student/ mentee may feel they know a lot about a lot. Effective student/mentee and mentor relationships work best when each is not lecturing the other.

- Using the mentoring experience as a disciplinary tool—the focus of a mentorship should not be disciplinary, it should be used as a coaching device to mentor the student/mentee (Pieper, 2004).

\section{Conclusion}

This article highlights some of the issues that have arisen in the mentoring process, primarily from the perspective of extensive educational experience (mentor) and business experience and literature searching (mentee). Additional insights were discussed regarding academic administrative involvement in the process. One further implication for research would be to collect real data from structured interviews of all interested parties and focus on what specific actions would or would not result in faculty hiring, promotion, and continuing academic growth.

In the meantime, some concluding comments are offered by the authors to stimulate thinking on this important subject and perhaps direct the effort of future researchers to pursue work on this topic. There are a number of things that all interested parties can do to support the professions they are examining, such as: 
Clarify and refine evaluation rules so that they are understood by all stakeholders;

Make operational the intangible factors in a way that can be agreed on by all stakeholders;

As far as possible, separate the role of mentor and evaluator, to ensure that both are used in the mentorship process;

If this separation is not possible, then train and support the supervisors, especially in the skills of observation and communication;

Train and support beginners in self-evaluation and communication;

Encourage dialogue between supervisor and newcomers; and

Encourage on-going formal evaluation so that there are no surprises in summative evaluation.

For future research, new ways of transferring know ledge should be researched to further enhance the overall mentor / mentee relationship. Knowledge is rooted in the concepts of organizational learning and organizational memory. When members of an university / organization collaborate and communicate ideas, teach, and learn, know ledge is transformed and transferred from individual to individual (Bennet \& Bennet, 2003). The term organizational learning refers to an organization's capability to learn from its past experience (DiBella, 1995). Before a mentee can improve, it must first learn. Learning involves an interaction between experience and competence. For example, in Communities Practice provide not only a context for newcomers to learn, but also a context for new insights to be transformed into know ledge (Wenger, 2002).

\section{References}

Argote, L. (1999). Organizational learning: Creating, retaining and transferring knowledge. Boston: Kluwer Acade mic.

Bennet, A., \& Bennet, D. (2003). The partnership between organizational learning and knowledge management. In C. W. Hols apple (Ed.), Handbook of knowledge management: Knowledge matters (Vol. 1, pp. 439-460). Heidelberg, Germany: Springer-Verlag.

Bourne, W. (2002). Do you have a mentor? You should. Logistics Management, 46(8), 96-97.

Brown, A. (2008, January). Mentoring at work-Getting the balance right. The British Journal of Administrative Management, 24-25.

Catling, T. (2008, January). Mentoring-The objective support that managers need. The British Journal of Administrative Management, 22-23.

Chaiklin, S., \& Lave, J. (Eds). (1993). Understanding practice: Perspectives on activity and context. Cambridge, UK: Cambridge University Press.

Cutler, A. (2005). Lonely at the top. Caterer \& hotelkeeper, 194(4387), 34-36.

DiBella, A. J. (1995). Developing learning organizations: A matter of perspective. Academy of Management Journal, 287-290.

Durett, J. (2006). Mentors in short supply. Training, 43(7), 14.

Franke, A., \& Dahlgren, L. O. (1996). Conceptions of mentoring: An empirical study of conceptions of mentoring during the school-based teacher education. Teaching and teacher Education, 12(6), 627641.

Gray, P. (1999, August). Knowledge management. Paper presented at the $5^{\text {th }}$ Americas Conference on Information Systems, Milwaukee, WI. 
Hanks, W. F. (1991). Forward. In J. Lave \& E. Wenger (Eds.), Situated learning: Legitimate peripheral participation (pp. 13-24). Cambridge, UK: Cambridge University Press.

Kram, K. E. (1988). Mentoring at work. Lanham, MD: University Press of America.

Kwan, M. M., \& Cheung, P. (2006). The knowledge transfer process: From field studies to technology development. Journal of Database Management, 17(1), 16-32.

Lave, J. (1991). Situated learning in commun ities of practice. In L. B. Resnick, J. M. Levine, \& S. D. Teasley (Eds.), Perspectives on socially, shared cognition (pp. 63-82). Washington, DC: A me rican Psychological Association.

Lave, J. (1996). Teaching, as learn ing in practice. Mind, Culture, and Activity, 3(3), 149-213.

Lave, J., \& Wenger, E. (1991). Situated leaming: Legitimate peripheral participation. Cambridge, UK: Cambridge University Press.

Le Maistre, C., Boudreau, S., \& Pare, A. (2006). Mentor or evaluator? Assisting and assessing newcomers to the professions. Journal of Workplace Learning, 18(6), 344-354.

Lee, A. (2007). How can a mentor support experiential learning? Clinical Child Psychology and Psychiatry, 12(3), 333-340.

Malhotra, Y. (1998). Tools at work: Deciphering the knowledge manage ment hype. Journal for Quality and Participation, 21(4), 58-60.

Manathunga, C., \& Goozee, J. (2007). Challenging the dual assumption of the "always/already" autonomous student and effective supervisor. Teaching in Higher Education, 12(3), 309-322.

Noe, R. A., Greenberger, D. B., \& Wang, S. (2002). Mentoring: What we know and where we might go. In G. R. Ferris (Ed.), Personnel and human resources management (pp. 129-174). Oxford, UK: Elsevier Science.

Pieper, S. K. (2004). The mentoring cycle: A six-phase process for success. Healthcare Executives, 19(6), $16-24$.

Rogoff, B. (1990). Apprenticeship in thinking: Cognitive development in social context. New York: Oxford University Press.

Rogoff, B. (1991). Social interaction as apprenticeship in thinking: Gu ided participation in spatial planning. In L. B. Resnick, J. M. Levine, \& S. D. Teasley (Eds.), Perspectives on socially shared cognition (pp. 349-413). Washington, DC: A merican Psychological Association.

Rogoff, B. (1995). Observing sociocultural activity on three planes: Participatory appropriation, guided participation, and apprenticeship. In J. V. Wertsch, P. del Rio, \& A. Alvarez (Eds.), Sociocultural studies of mind (pp. 139-203). Cambridge, UK: Cambridge University Press.

Rose, B. (2008, March 24). Chicago Tribune Your Space colu mn: Best mentors give challenging advice, critic is m. Chicago Tribune, pp. 1-2.

Rosser, M. H. (2005). Mentoring from the top: CEO perspectives. Advances in Developing Human Resources, 7(4), 527-539.

Rosser, M. H., \& Egan, T. M. (2003). Types and functions of mentoring relationships: A review of the literature. In S. Lynham \& T. M. Egan (Eds.), Proceedings of the 2003 Academy of Human Resource Development Conference (pp. 928-934). Minneapolis, MN: Academy of Hu man Resource Development.

Schmidt, M. (2006). Mentoring and being mentored: The story of a novice music teacher's success. Teacher and Teacher Education, 24(1), 635-648.

Schrage, D. (2007). Officer mentoring preserves fire service heritage. Fire Engineering, 7(160), 83-86.

Swap, W., Leonard, D., Shields, M., \& Abrams, L. (2001). Using mentoring and storytelling to transfer knowledge in the workplace. Journal of Management Information Systems, 18(1), 95-114. 
Ten points to help you sell mentoring for your a mbivalent partners-Again. (2007). IOMA's Report on Compensation and Benefits for Law Offices, 8, 4-6.

Ugrin, J. C., Odom, M. D., \& Pearson, J. M. (2008). Exp loring the importance of mentoring for new scholars: A social exchange perspective. Journal of Information Systems Education, 19(3), 343-350.

Wanberg, C. R., Welsh, E. T., \& Hezlett, S. A. (2003). Mentoring research: A review and dynamic process model. In J. J. Martocchio \& G. R. Ferris (Eds.), Research in personnel and human resources management (vol. 22, pp. 39-124). Oxford, UK: Elsevier Science.

Wenger, E. (1998). Communities of practice: Learning, meaning, and identity. Cambridge, UK: Camb ridge University Press.

Zack, M. H. (1999). Managing codified knowledge. Sloan Management Review, 40(4), 45-58.

\section{Biographies}

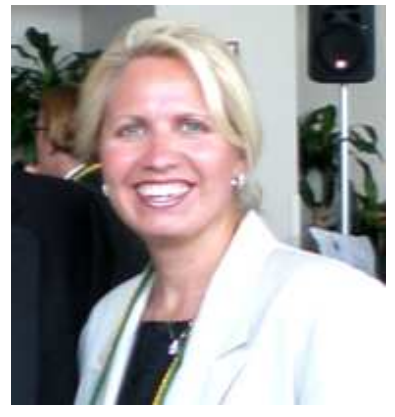

Dr. Kathleen Terry is currently a Business / IT Consultant with a background in medical, financial, telecommunications and IT services Fortune 100-500 organizations. Dr. Terry is a Partner of TEEG Ventures Group, LLC, a consulting business firm specializing in "Process Improvement within Organization and Improving the Quality of Knowledge." Kathleen has over 18 years of management experience across a variety of industries: Medical, Financial, IT Software and Telecommunications. In conjunction with corporate experience, Kathleen has worked at various universities and colleges as an adjunct professor for 4 years. Her areas of expertise over the years have been management of information systems, quality processes surrounding IT, strategic organizational restructuring, change management and IT management. She has participated in national conferences and has published articles for the conference proceedings. Prior to her IT experience, she started her career in the medical profession as a registered nurse. She worked in medical facilities for approximately 10 years, leading other medical personnel in improving their daily work. She is a certified Registered Nurse, has an Undergraduate Degree in Business Management \& Information Technology Management, Masters in Business Management and a Doctorate in Business Management / Entrepreneurship \& Information Technology Management.

Dr. Robert DeMichiell is President, Robert DeMichiell \& Associates, a consulting and seminar business firm of over twenty five years specializing in "Managing People, Information and Work." In addition to bus iness, government, and education consulting experience, he was a full time faculty/administration member of two educational institutions, the U. S. Coast Guard Academy in New London, Connecticut and Fairfie ld University in Fairfield, Connecticut. He retired as Professor Emeritus from both of these institutions. During the past five years, he has taught business doctoral students for Nova Southeastern University in Fort Lauderdale, Florida where he was Visiting Professor. His areas of expertise over the years have been computer science, information systems, and IT management. He has participated in numerous national and international conferences and has published over one hundred artic les in professional journals. His text, Managing Information Across the Enterprise, with coauthor, Robert Wysocki, Wiley 1997 and its companion text, Active Learning Approaches, have been used for undergraduate and graduate students. 


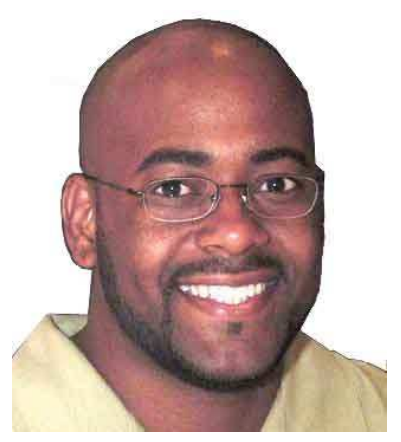

Mr. Clarence Williams is President, Williams Consulting Group, Inc., a consulting business firm specializing in online training and works one-on-one with colleagues and customers in leadership, startup businesses, and strategic management. Clarence is a certified Project Management Professional (PMP) and has an Undergraduate Degree in English studies. 